\title{
Transatlantic Re-soundings: Fats Waller's London Suite and the Jazz Atlantic
}

George Burrows*

Abstract: Thomas “Fats” Waller's London Suite was composed and recorded by the African-American pianist, entertainer and bandleader during his 1939 visit to Britain. This article is the first to examine the suite for its representation of a hybrid musical style. Its mix of stylistic markers of "hot" jazz with melancholic "sweet" music that references European classical music made the suite distinctive in Waller's output and reflective of a different sort of hybrid musical aesthetic that came with his transatlantic musical tourism. Some original archival research is presented to help document the wartime circumstances that prevented the release of Waller's recording until 1951. In the period between 1939 and 1951 Ted Heath's all white British band released an orchestrated swing version of Waller's piano suite. This is shown to be in many ways "hotter" in its swing than Waller's original recording and the album was widely distributed in the United States. Analysis of contemporary reviews shows only when Waller's recordings resurfaced was there a change in critical attitudes towards the hot jazz identity of Heath and Waller. Thus, the travel of Waller's suite, back and forth across the Atlantic, shaped and reshaped not only its musical style but also perceptions of Waller and Heath with respect to apparently essential concepts of race and nation that were bound up with stylistic definitions of hot authenticity in jazz. Ultimately, Waller's suite suggests the operation of a Jazz Atlantic, an outer-national critical conception founded on Paul Gilroy's notion of the Black Atlantic,

\footnotetext{
* George.Burrows@port.ac.uk
} 
which might be extended to encompass a whole body of such hybrid-styled musical works and the critical discourse that surrounds them.

Keywords: Fats Waller; London Suite; Ted Heath; Toots Camerata; RMS Queen Mary; hot jazz; sweet jazz; transatlantic hybridity; transatlanticism; London Records; Black Atlantic; jazz Atlantic 


\section{Introduction}

This article explores the London Suite, a set of six piano pieces, each depicting a different district of London, that was written and recorded in 1939 by the AfricanAmerican pianist, entertainer, bandleader and composer Thomas "Fats" Waller (19041943). Despite it being Waller's most substantial work for his own instrument, the suite has not received scholarly attention before, except in brief considerations in the standard reference works on Waller. ${ }^{1}$ However, this article shows that Waller's suite deserves closer attention and not least because the transatlantic context and content of the music is highly illuminating of broader issues of national and racial identities that are bound up with notions of musical style in jazz. Furthermore, this investigation of Waller's suite suggests a way of listening to the effects of transatlanticism in music that takes account of the social politics that are bound up with it.

A remarkable set of wartime circumstances meant that although Waller recorded his suite when he was in London in 1939, it actually first became known to the American public through a version for Big Band that was released in 1948 and featured Ted Heath's all-white British band. In fact, when Waller's piano recording was eventually released by HMV in 1951, critical expectations were confounded not just by its poorer audio quality but also by its comparative lack of "hot" jazz content, which, ironically, was more present in Heath's white-British version. In effect, the London Suite, in its transatlantic hybridity of European and African-American musical styles, upset the highly racialized critical image that had built up around Waller and his typical style of hot jazz music and entertainment. ${ }^{2}$ In view of the transformation of Waller's music and image as a result of his suite's crisscrossing of the Atlantic, the article ends by reflecting on the London Suite in order to break new theoretical ground. This reflection serves to develop Paul Gilroy's 
highly influential notion of the Black Atlantic, which he developed out of his analysis of the transnational attitudes of leading black political thinkers. These people were troubled by the modernist conjunction of nationalism, ethnicity and authenticity that supported institutionalised racism. Thus, they drew upon strategies rooted in the experience of the Black diaspora to point beyond pernicious nationalist agendas. Gilroy thus explores transatlantic Black expressive cultures (including music) that he finds arising from the shared experience, memory or imagination of slavery.

Gilroy frames his critical enterprise by evoking one of Mikhail Bakhtin's 'chronotopes', the image of the sailing ship, which for Gilroy not only represents a powerful cultural memory of the 'middle passage' and the promise of a redemptive return to an African homeland for blacks, but also the vital movement of people and artefacts in transnational micro-political subcultures. ${ }^{3}$ Gilroy doesn't really develop the idea of the ship chronotope and gives relatively little attention to jazz in that context, but Waller's London Suite suggests the action of a more contemporary 'floating' subculture that I will call the 'Jazz Atlantic', founded on Gilroy's chronotopic Black Atlantic. This extrapolation has particular merit for understanding the way that cross-Atlantic travel, ships and encounters aboard them can account for a transnational, cross-racial hybrid character that can be found in interwar jazz. This musical hybridity is often unacknowledged and little understood because it does not chime with the racialnational essentialism that has been common in jazz criticism that has too often aimed to keep jazz and its subjects enslaved as a wholly black-American music despite its ever-increasing globalization. 
This essay argues that the unusual musical character of Waller's suite and its re-appropriation and reception is evidence of the functioning of the Jazz Atlantic as a vital re-formative space in the interwar period. This reflective, critical and re-formative conception of a mobile musical culture is founded on evidence of transatlantic mobility, production, consumption and interaction that is exemplified in Waller's suite. Ultimately the suggestion is that by attending to a body of such transatlantic works and practices, the ideological basis for categorisations such as "hot" and "sweet" in jazz music and, by extension, for racial segregation in the societies which produce such music is critiqued in the face of the hybridity and pluralism that is suggested in the style of Waller's exemplar of a Jazz Atlantic.

\section{Waller comes to London: Stylistic hybridity in Waller's London Suite}

According to the Encyclopedia of Popular Music, "Waller was one of the first jazz

figures to popularize "hot' music". The adjectival terms "hot" and "sweet" appeared in some of the earliest polemical criticisms of jazz to emerge from Europe but, in an indication of the operation of what I shall call the Jazz Atlantic, such terms were soon in general use on both sides of the Atlantic. ${ }^{5}$ The adjectives sought to differentiate between supposedly authentic (black-rooted) jazz artistry and that seemingly more derivative and deliberately commercial fare, which seemed only to play up to the stylistic markers and emotions of "true" jazz. There is a gendered and racialized aspect to this differentiation: the "sweet" style is figured as a contrived product of white industry that is feminine in its easy-listening emotionalism, whereas the "hot" style is associated with a decidedly black masculinity and authenticity. ${ }^{6}$ This black masculinity was of the heroic-athletic sort exhibited in the so-called "cutting" contests 
of the 1920s and 30s in which jazz pianists would try to outdo each other with evermore virtuosic and up-tempo improvisations on a given tune.

Waller was a musician that refined his performing through Harlem "cutting" contests with the likes of James P. Johnson (1894-1955). This schooling in such hotjazz masculinity, together with experience gained in Harlem's theatres and nightclubs, meant Waller became a great showman, a highly charismatic singer and a brilliant hot-jazz pianist. ${ }^{7}$ He was a master of the showy pianistic style that came to be known as "stride" piano, so called because the left hand of the pianist was required to repeatedly leap (or stride) at speed between single notes, octaves or tenths in the bass register and triads in the tenor register of the piano. The right hand, meanwhile, offered ever more elaborate, surprising and inventive variations on a melody in the treble over this accompaniment. Many of Waller's recordings, especially his solo piano ones, are ebullient showpieces that demonstrate his virtuosity or else they are comedic songs that exploit his larger-than-life persona. ${ }^{8}$ Thus, Waller reconceived some of the greatest and some of the tawdriest of interwar popular songs, sometimes performing on his own and sometimes accompanied by a band.

Waller's London Suite is distinctive in Waller's output for its emphasis on a comparatively more serious and poignantly impressionistic music. This contrasts the upbeat-comedic vein of his other recordings. The melancholic character of the suite is underpinned by a high proportion of the constituent pieces that are set in slower tempi than is the norm for Waller's output. As Alyn Shipton notes of the six pieces of the London Suite,

Only one of these pieces ["Piccadilly"] is an up-tempo stride showstopper [...] All the others are medium or slow in pace, and tread a narrow line between 
being as inconsequential as cocktail-bar music on the one hand and sending up the light classics on the other, while not failing to remain jazz performances. ${ }^{9}$ The analysis that follows demonstrates that it is precisely the stylistic mixture of sweet-styled functional music that references both European classical music and hot American jazz that constitutes the transatlantic content of Waller's composition. It seems to me that this hybrid style resulted from Waller's experience as a tourist who was musically active with "other" musicians and audiences, both in crossing the Atlantic and in London. To explore this notion of transatlantic musical activity a little further, it is useful to firstly establish the situations in which Waller's suite was conceived and composed.

The London Suite resulted from a discussion that was conducted between Waller and his manager, Ed Kirkeby, during their crossing of the Atlantic aboard the luxury ocean liner the RMS Queen Mary in March $1939 .{ }^{10}$ On a previous crossing to Britain, in July 1938, Waller had made it his practice not only to socialise with his manager and fellow passengers but also to sit in with the ship's resident band, playing piano for and with them until the early hours of each morning. ${ }^{11}$ He was fuelled in this enterprise by whisky, which by this stage of Waller's alcoholism was always present in a bottle on the piano while another was usually stashed under it. ${ }^{12}$ On his next trip to Britain in 1939 Waller again played for and with the all-white ship's orchestra.

The band of the Queen Mary was a versatile British ensemble led by a violinist named Bernard "Bunny" Rowe. ${ }^{13}$ We can get a sense of the aesthetic of the band from a British Pathé newsreel of $1938 .{ }^{14}$ In the first part of the film, a fulsome rendition of "The Fleet's in Port Again", the bandsmen play instruments that are traditionally associated with hot jazz but in the second part they take up string instruments to perform "It Looks Like Rain in Cherry Blossom Lane" in a sweet style 
and in an orchestration more indebted to the instrumentation of European classical music. ${ }^{15}$ However, none of the music represents hot jazz and neither is it really classical music. It is rather a hybrid, dance music of the sort of lightly jazzy but inbetween-genres kind that Shipton points to in Waller's suite. Theirs is a sweet transatlantic aesthetic that mixes signifiers of African-American jazz (saxophones, syncopation etc.) with more European, composed and indulgently "sweet" music (strings, sinuous melody, etc.).

It wasn't just the band of the Queen Mary that represented such transatlantic musical hybridity for Waller but also his experience of audiences in Europe. In an interview with World-Telegram, which reflected on Waller's 1938 European tour, he stated:

Throughout the British Isles and Scandinavia, audiences like to listen $[\ldots]$ Unlike the jitterbugs over here, they will often stop while dancing as a band builds up to the climaxes. I never saw such an intelligent appreciation of swing. [...] For years I've been trying to sell the idea of softer stuff over here but I've never been able to get away with it until now [...] I used to tell 'em down at Victor I ought to tone down, but they'd say, "No, go ahead and give 'em that hot primitive stuff; that is what they want.” But I don't think so any more [... ] I think Europe's way is the right way, and I think it'll take over here, and I hope it does before we lose our eardrums. ${ }^{16}$

This characteristic quote shows Waller's awareness of the different tastes and practices of European audiences and his experience of Europe as a place where he could make and record music that flouted Victor's concern that he should pander to the racialized hot-jazz expectations of American listeners. In other words, Waller's transatlantic musical tourism showed him new stylistic possibilities that were not so 
bound by the racial essentialism that he felt constrained him to particular practices and categories of music at home.

The London Suite demonstrates this hybrid style even in its opening movement, "Piccadilly", which, as Shipton pointed out, is the one nearest to Waller's usual style of ebullient stride piano. ${ }^{17}$ The piece is actually an extension of the minor key third strain of Waller's "Valentine Stomp", a stride-piano showpiece he recorded in 1929. Waller first extracted and extended this strain in his "Russian Fantasy", a piece recorded in 1935 under the pseudonym of Flip Wallace within a set of medleys that were intended for radio companies to use to fill airtime between scheduled programmes. The "Russian Fantasy" version got its name, no doubt, because it quotes the distinctive opening motif of Rachmaninov's Prelude in C-Sharp Minor, Op. 3, No. 2 (although rendered by Waller in $\mathrm{C}$ minor) in its closing bars. This quotation remains in "Piccadilly" and that, together with the choice of minor-key source material, gives this first movement of the London Suite an immediate feel of European musical seriousness, despite its hot-stride sensibility.

The second movement of the suite, "Chelsea", although in G major, has a feeling of sweet musical indulgence and melancholy in its ballad-like theme. After the cursory four-bar introduction, the piece offers two 32-bar choruses made up of eightbar phrases that are set in the form ABAC. The simple melody-and-accompaniment texture of the opening chorus is coloured by some bluesy harmonies that suggest major/minor ambiguity. The second chorus is essentially a variation on the first in which the mix of stride and classical piano styles are again apparent. For example, the treatment of the ballad theme in loud homophonic chords, occupying both of Waller's hands, in the second A section of the variation chorus, gives an impression of a Romantic-period piano virtuoso such as Rachmaninov or Liszt. Cadenza-like ninth- 
chord arpeggios, which roll up and then down the keyboard ahead of the poignant closing bars, only reinforce the "classical-music meets hot-stride" feel.

The 32-bar AABA chorus structure of "Soho", which follows Waller's standard four-bar introduction, moves the suite away from classical pianism towards sweet dance-band music. The A sections of the chorus are reminiscent of Edgar Sampson's 1934 standard "Stompin' at the Savoy" and the B section is clearly based on the chord changes of the bridge of Gershwin's “They Can't Take That Away from Me". Both pieces were popular sweet dance-tunes of the 1930s and Waller infuses them with a melancholic quality which, one can argue, sweetens them further. Thus, the distinctive harmony of the opening of Sampson's famous chorus, with alternating dominant and tonic chords, is altered by flattening the sixth and ninth degrees of the dominant chord and having the flat sixth, placed in the uppermost voice of the chord, fall to a dissonance (the ninth) in the following tonic chord, , rather than rise to a consonance as in Sampson's piece. This brings the sweet melancholy to the music, which is reinforced in the B section because the Gershwin chord changes there start in the relative minor and only progress to the dominant (a major chord) gradually through a chromatic descent in the bass. The cycling of all the chromatic notes in the minor-third interval between B and D in Waller's right hand over these changes only emphasises the 'sweet' jazz melancholy of the track.

"Bond Street", which Waller's manager insisted was a tone poem depicting a liaison with a prostitute that worked that street, is founded on a walking bass in $\mathrm{F}$ major, featured in the four-bar introduction. ${ }^{18}$ It is otherwise another 32-bar AABA chorus followed by a stride-styled variation of that chorus. However, in the variation chorus, Waller alters the chord changes of the first A section to give it the character of a secondary bridge section, perhaps to follow his manager's narrative. On Waller's 
recording drums are vaguely audible at moments on this track and, indeed, Max Lewin is credited on the HMV discs but is not heard elsewhere in the suite. ${ }^{19}$ If the bass line, drums and extended chords suggest hot jazz then the sustained melody in Waller's right hand points towards a sweet dance-band sensibility.

"Limehouse" and "Whitechapel" belong together for they represent the "other" Chinese and Jewish ethnicities resident in those respective districts of London at the time. They depict these ethnicities using longstanding musical clichés. "Limehouse", another subdued AABA-structured variation piece in F major, thus contains some pseudo-Chinese pentatonicism and a preponderance of bell-like sonorities and harmonies featuring parallel fourths. ${ }^{20}$ The "Whitechapel" movement, however, returns the suite to the minor key to evoke a decidedly Eastern-European Jewishness to round off the suite. ${ }^{21}$ This slow movement, performed with plenty of rubato by Waller, is the most sophisticated in terms of thematic development and musical variation. The melodic material is reminiscent of Liszt's Hungarian Rhapsody No. 2, and Waller also quotes from Grieg's Peer Gynt Suite at the end of his stridestyled variation. This quotation actually forms a bridge to an additional variation of the theme that returns listeners to the world of the Romantic-period piano virtuosi with fortissimo reiterated chords and then, after a brief return of a stride-piano style, in the arpeggio cadenza-like flourishes that propel the piece to it subdued close. After the classical-piano virtuosity, however, the final C-major chord contains an added sixth just to remind us that this is, in the end, still jazz despite its hybrid, Europeaninfluenced musical style.

Therefore, it seems that Waller's encounters with the different attitudes of the British musicians aboard ship and of the tastes of European audiences engendered a concern to present a more subdued, sweet and composed style of jazz in his suite, one 
marrying American hot pianism with a white-European dance-music aesthetic indebted to classical music. This was only feasible because he was removed from his American record company and their concern that he should pander to the assumed hot-jazz expectations of American listeners. Such listeners would have to wait for more than a decade to hear Waller's own rendition of his hybrid transatlantic style of jazz. In the meantime, they were served a version of Waller's suite that in its BigBand swing was altogether more in line with what might be expected from a hot musician like Waller.

\section{London comes to Waller: Ted Heath's re-authentication of Waller's suite}

The story of Waller's composition and recording of the London Suite is detailed in business correspondence preserved in The Wallace Theodor "Ed" Kirkeby Collection

of the Institute of Jazz Studies in Rutgers University Libraries, Newark, New Jersey. ${ }^{22}$ One letter of 23 November 1950 between Waller's manager, Ed Kirkeby and Ben Kemper of the RCA Victor contains the following summary of events:

In 1939, Fats and I made our second trip to England to play a tour of the Moss Empire Theatres here. While in London, Fats had been commissioned by Jimmy Phillips of the Peter Maurice Music firm, to write six piano solos for a contemplated music folio that they wished to publish, and one morning we ambled over to a private studio that had been retained by Phillips for an hour so that Fats could do some work on the compositions. Upon our arrival there, I found that Fats was in no mood to bother himself about technical things; so I suggested that he do some work on the idea I had advanced to him while coming across on the Queen Mary: i.e., a descriptive portrayal of London life as depicted by the well known sections of the city; such as Piccadilly, Soho, 
Limehouse, etcetera. Fats immediately responded to the idea, and became so inspired that he actually composed and recorded the entire London Suite in the hour we had allocated to us by the studio. ${ }^{23}$ I described each section of the city to him, one after the other, and those word pictures were sufficient to enable him to capture the mood, and perform a feat which further establishes Tom Waller as a pure inspirationalist; and one of the truly great musical geniuses of his time. Of course, I immediately made arrangements for Fats to record the suite for HMV to put it in permanent form. ${ }^{24}$

Other letters between Kirkeby and Jimmy Phillips of the British music publisher Peter Maurice Music and between Kirkeby and other executives with the Gramophone Company (HMV) and their American affiliate, RCA Victor, show frustrating delays in the release of the London Suite. They reveal that Phillips waited on the American music publisher Shapiro Bernstein and only published the transcribed score of Waller's recording in 1947, after it was apparent that the American publisher was not interested in doing so. ${ }^{25}$ Furthermore, HMV held back release of Waller's recordings of the suite and that, together with the difficulty in sending masters of recordings safely across the Atlantic to the US during the war, meant that Victor did not release them either. ${ }^{26}$ In the absence of a release of Waller's recordings of the suite, Kirkeby consorted with Phillips, without much success, to get Glen Miller's arranger, Jerry Gray, or else arrangers for Paul Whiteman to introduce Waller's suite to the American public. $^{27}$

Waller died unexpectedly in December 1943 and this pushed Kirkeby to secure the release of Waller's HMV recordings of the suite. ${ }^{28}$ However, a letter to Kirkeby dated 3 April 1944 from H. C. Darnell of RCA Victor's Copyright Department states, 
We have just received a cable from the Gramophone Company stating that Fats Waller's "London Suite" masters have been destroyed and they are, therefore, unable to supply us with stampers. ${ }^{29}$

Thus, Kirkeby wrote to Jimmy Phillips on 2 May 1944 to see if copies of the London Suite records were in the possession of Peter Maurice Music. Phillips replied on 31 May 1944 that he would send test pressings of the HMV records and they eventually made it to Kirkeby, albeit with some damage, and he forwarded them to RCA Victor for re-mastering. ${ }^{30}$ This was completed during October 1946 but, because of the poor quality of one of the source records, neither Victor nor HMV saw fit to issue the London Suite before a British band released a version in April 1948. This Big-Band version appeared in a smart album on a new record label that was specifically designed to exploit the American market. ${ }^{31}$ Thus Waller's depiction of London was sent back across the Atlantic in a version by a leading British swing band.

In 1947 the English trombonist Ted Heath was emerging as the leader of a band of highly accomplished jazz musicians that was modelled on Glen Miller's Air Force band that had been resident in Britain during the war. However, during the earlier 1940s, Heath had struggled for talented instrumentalists, money and exposure. Thus, when Heath's band was contracted to provide music for London Town, a bigbudget British film-musical of 1945, Heath agreed to let the American trumpeter and arranger Salvatore "Toots" Camarata take over leadership of his band for the film. Heath learned a lot from Camarata, whom he later described as "a musician of the highest ability, a man who knew just what he wanted musically and precisely how to get it." ${ }^{, 32}$ Heath's enduring friendship with Camarata proved to be useful when it came to recording and distributing a version of the London Suite. 
By 1948 Camarata had become head of the London Records, a subsidiary of Decca devoted to the distribution of British music in the United States. At that time American artists were unable to record due to a recurrence of a ban imposed by James Caesar Petrillo, President of the American Federation of Musicians. Petrillo sought to ensure fairer royalty payments for musicians but the industrial action he sanctioned effectively halted US record production for two years from August 1942 and, without a resolution to the dispute, a fresh ban was imposed in 1947 to start in January $1948 .{ }^{33}$ The ban opened up the American market to imported music on labels like London, and thus Camarata's acquaintance with Heath meant that he wasted no time in signing up the Englishman's band to record Waller's London Suite for one of London's first glossy album releases in the US. ${ }^{34}$ Heath hurriedly put a quartet of arrangers on to reworking Waller's suite from the newly published Peter Maurice piano score. ${ }^{35}$ In the spring of 1948 a handsome set of three 78-rpm records entitled "Fats" Waller's “London Suite” was released by London Records and widely distributed in the United States. The various movements of Waller's suite were presented in a different order in Ted Heath's recording and each movement was reconceived such as to show off the wide variety of dynamics, textures and timbres of Ted Heath's impressive Big Band: from powerful tutti passages led by brash trumpets, to sparse chamber-jazz sections in which the rhythm section, with or without soft riffs from the band, back improvising soloists. Waller's classical-piano virtuosity was entirely removed in the rearrangements and a fulsome swinging band and jazz-solo virtuosity replaced it. Rich orchestrations, altered chord voicings and harmonies and driving rhythms replaced the melancholic, sweet-yet-serious tone of Waller's piano recording with a much more driven and hot-swing sensibility. Heath's recording of the London 
Suite thus put more hot jazz into Waller's composition and this meant it chimed with the established critical image of Waller as a hot African-American jazz musician.

A review in the Hollywood Lead Sheet, a Californian trade publication, noted that the Heath album presented Waller's hitherto unreleased suite in a vivid modern recording and raved about the Heath band's reinterpretations, describing them as "excellent by anyone's standards". ${ }^{36}$ Irving Kolodin, writing in the Saturday Review of Literature described the "irresistible compulsion" of the Heath band in Waller's suite and suggested the different movements "remind us that Waller needed but one thing to become as original a force in jazz as Duke Ellington. That was what was never granted to him by his line of work - opportunity." ${ }^{37}$ A review in The New Yorker, although critical of a mismatch between the eloquent liner notes and Waller's musical impressions of London, described Heath's recording as “vigorous and appealing' and Waller's music as 'refreshing". ${ }^{38}$ Howard Taubman, writing in the New York Times, praised Heath's band on the album as "jazz musicians of class". 39 Thus American reviewers tended to lavish praise upon Heath's band, comparing it favourably with leading American orchestras, and thereby pointed to its hot-swing authenticity and the opportunity that this afforded Waller's unreleased music.

When Waller's rather scratchy 1939 recording of the London Suite was eventually released in 1951 Gramophone magazine's reviewer wrote, “I cannot help feeling that it was more effective as orchestral music than it is as the piano work as which it was originally written." ${ }^{, 40}$ Indeed, many American critics and listeners also preferred the Heath version as more than a million copies of the 1948 album were sold and Heath went on to produce a second recording of Waller's suite in 1954. This second revision was presented on an LP in high-fidelity sound and featured new arrangements of Waller's music, all by Reg Owen. ${ }^{41}$ However, by the time this LP 
appeared, reviewers had had access to Waller's 1939 recordings and thus turned more critical in assessing the British band's recording. Paul Sampson, writing in the Washington Post, suggested Heath's new version was an improvement on his 1948 one but stressed, "It is hard for a big band to capture the lilt of these compositions, and in some of the sections the arrangements are too heavy and too loud." ${ }^{42}$ It seems then, by this point, Heath's fulsome British swing did not appear authentic enough in its hot-jazz style in view of the availability of Waller's more sweet-styled and melancholic piano version. Suddenly, there was a need to re-conceive of Heath's revision of the suite as too heavy-handed and as Waller as a figure capable of "serious" music beyond the virtuosic or comedic entertainment with which he had been associated as a "hot" jazz musician.

\section{Conclusion: From the London Suite to the Jazz Atlantic}

The story of the conception, composition, recording, rearrangement and re-conception of Fats Waller's London Suite and its re-interpreters shows the re-formative power of transatlantic movement and exchanges on meanings and identities in jazz. Such a performative transatlantic notion of jazz flies in the face of enduring racialized and nationalistic narratives of authenticity that, as Scott DeVeaux has documented, have long persisted in jazz historiography. ${ }^{43}$ By analysing the effects of Waller's transatlantic experiences and how his suite reflects his racialized position as a hot-jazz musician, this article has pointed towards the notion of the Atlantic as a vital, developmental and critical space operating between, about and beyond such notions of musical style and authenticity that often support patriotism, racism, and other socio-political ideologies by reason of appearing as sensible and stable rather than as constructions. I want to end by suggesting that a Jazz Atlantic, which the 
transatlanticism of Waller's suite exemplifies, operated in and even beyond the interwar period and is a specifically musical instance of the "Black Atlantic" formation explicated by Paul Gilroy in his seminal 1993 volume, The Black Atlantic: Modernity and Double Consciousness.

The many musical exchanges between Europe and America and, indeed, between such places and Africa and the rest of the Atlantic world, have not, in my view, been adequately considered by scholars for their full critical potential. In fact, jazz is not much mentioned in Gilroy's chapter on music and yet the movement of jazz musicians and records around the Atlantic has often been documented. ${ }^{44}$ However, the full implications of the movements of jazz music or the visits to Europe of seminal figures of American jazz, such as the Original Dixieland Jazz Band (in 1919), Louis Armstrong (in 1932) and Duke Ellington (in 1933), or of visits to America by such British musicians as Reginald Foresythe, Ted Heath have not yet been much considered for their potential to critically illuminate jazz ideologies and the broader cultures and social discourses that underpin them. ${ }^{45}$ Furthermore, the work of shipboard musicians like Bunny Rowe (considered above), who were constantly in transit across the Atlantic aboard ocean liners and thereby continually interacted with different musicians and ideas from all manner of places and positions, is worthy of more attention, given its broader implications for understandings of jazz music or the Atlantic as critical formations.

When taken together, the transatlantic movements of musicians and the associated exchanges of music and ideas surrounding them in and after the interwar period can be figured as a whole network of interactions within a formative and critical musical economy that I would like to call the Jazz Atlantic, following Gilroy's notion of the Black Atlantic. Waller's London Suite, as an exemplar of the musical 
productions of the Jazz Atlantic, shows a particular form of the "double consciousness", which is central to Gilroy's thesis, in its musical hybridity; mixing, as it does, hot and sweet, jazz and classical, American and European, black and white stylistic markers in a way that is revealing of broader forces of social containment and segregation. ${ }^{46}$ Such hybrid music of the Jazz Atlantic is music that does not wholly fit within standard categories but goes beyond them and thus critically reflects upon them. In doing so, this study has shown that the Jazz Atlantic provides a space within which figures like Waller could move, interact and reconceive of their music outside of the pressures imposed on them at home. This allowed it to be refreshed by the experience of "other" Atlantic peoples and their different approaches and ideas.

This conception of a Jazz Atlantic ultimately suggests a means for changing musical conceptions of style and genre and thereby challenging the ideologies on which they are founded. Thus, as I have shown, Ted Heath's band was heralded as an appropriately hot-swing outfit for importing Waller's London Suite to the United States in 1948. However, when Waller's melancholic piano recordings were issued and revealed the falsity of the confinement of Waller to the hot-jazz category, Heath's hot reinterpretations no longer seemed so appropriate, and both the Englishman and the African American had to be reassessed together with underlying notions of jazz authenticity and integrity. In other words, it was the transatlantic formation, reformation and movement of the music and associated ideas within a Bakhtinian chronotope of the Jazz Atlantic that led to critical reflection and reappraisal.

Gilroy states that his book aims to "repudiate the dangerous obsessions with 'racial' purity which are circulating inside and outside black politics" in the hope that “the book's heartfelt plea against the closure of categories with which we conduct out political lives will not go unheard." ${ }^{47}$ He goes on, "The history of the black Atlantic 
yields a course of lessons as to the instability and mutability of identities which are always unfinished, always being remade. ${ }^{, 48}$ In answer to Gilroy's call, this small "lesson" in musical transatlanticism and hybridity, emerging from a suite written by a touring African-American musician that was otherwise confined to a racially defined hot category of jazz, serves to reinforce the idea that such instances of transatlantic exchanges are vital for what they reveal of categorisation and its ideological basis. By attending to these figures and their transatlantic interactions, we can not only indulge in a rich body of fascinating and often unjustly neglected music like the London Suite, but also perceive how it helped break down some of the restrictive categories structuring the social world, enabling it to become resoundingly more plural.

\section{Note on contributor:}

George Burrows is Section Lead and Principal Lecturer for Performing Arts in the School of Media and Performing Arts at the University of Portsmouth. He has studied socio-political discourses associated with musical theatre and jazz of the interwar period and, more recently, his research has focused on performance cultures aboard ocean liners and cultures of listening that arose with technological developments in sound recording and reproduction. He is co-founder of the Song, Stage and Screen international conference and the peer-reviewed academic journal, Studies in Musical Theatre. He directs the University of Portsmouth Choir and has led them in concerts in the UK and abroad since 2003. He recently led the choir in a practice-research project exploring reactions to diva-performance in a recreation of an 1812 version of Handel's Messiah. 
${ }^{1}$ See Shipton, Fats Waller, 112-113; Waller and Calabrese, Fats Waller, 139; Machlin, Stride, 6; Fox, Fats Waller, 67-68; Kirkeby, Ain't Misbehavin', 206-207; Shipton, Cheerful Little Earful, 145-146, Vance, Fats Waller, 125-126.

${ }^{2}$ I am mindful of the sort of argument put by Helen Taylor that "Jazz was always hybrid, played from the outset by mixed race and white musicians, using European forms and often relying on extended visits to Europe." See Taylor, 2001, 23. However, such hybridity is most often lost in critical discourses about jazz which tend towards racial essentialism in the concept that the only "true" jazz is that produced by or about the experience of African American musicians.

${ }^{3}$ Gilroy, Black Atlantic, 4 \& 17.

4 “Waller, Fats - Ain't Misbehavin'.” Encyclopedia of Popular Music, 4th ed.. Oxford Music Online. Oxford University Press, accessed July 18, 2016, http://www.oxfordmusiconline.com/subscriber/article/epm/89898.

${ }^{5}$ The term "hot" was applied to jazz by the mid-1920s in response to the "Symphonic Jazz" that became popular with the success of Paul Whiteman and his band in concerts and on records. Louis Armstrong's recording bands known as the Hot Fives and the Hot Sevens, were thus differentiated as "hot" ensembles and the term probably entered the critical literature in the first jazz magazine edited by the French critic Hugues Panassié. Panassié went on to produce a book, Le Jazz Hot (1934), which is effectively a manifesto for hot jazz as the only rightful jazz in the face of the prevalence of seemingly more commercial and derivative forms. See Panassié, Hot Jazz.

${ }^{6}$ An important aspect of the gendering of sweet music as feminine is its association with the body through dance as such music was the staple of dance bands in Britain and America.

${ }^{7}$ Machlin, Stride, 11.

8 “A Handful of Keys" is perhaps Waller's most famous stride-piano solo and "You're Feet's Too Big" is a notable examplar of his comedic song performances. They can be heard together in his 1943 radio "Command Performance" available online at http://chirb.it/D2FL8N

${ }^{9}$ Shipton, Cheerful Little Earful, 145.

${ }^{10}$ Kirkeby remembered, "On the boat, Fats and I had talked about a possible musical suite to be based on the various aspects of London.” Kirkeby, Ain't Misbehavin', 206. Vance reports “'On the way over [from New York to Southampton], Kirkeby and Waller discussed, as a fancy, an improvised suite 
based on impressions of certain sections of London, with Kirkeby providing basic descriptions and Waller taking off on the loose themes supplied.' Vance, Fats Waller, 125.

${ }^{11}$ Kirkeby recalled, "The orchestra boys had the toughest work-out they ever had, for Fats kept them at it till four o'clock in the morning, but they enjoyed themselves and the wonderful jazz grounding free, gratis and for nothing." See Kirkeby, Ain't Misbehavin', 196.

${ }^{12}$ Waller's capacity for alcohol was legendary by the late 1930s and is especially well documented in John S. Wilson's appreciation in Gottleib, Reading Jazz, 393-400. The concert promoter, Ernie Anderson, cited Waller's alcoholism as a significant factor in the failure of Waller's 1942 Carnegie Hall concert, which featured his London Suite. See Wright, Fats in Fact, 391.

${ }^{13}$ Waller was even pictured with the band and he represents a large and characterful black presence amongst the otherwise all white bandsmen. See:

http://www.fatswaller.org/ filesdiscopg/queenmaryphotobig.jpg

${ }^{14}$ The film is viewable at http://www.britishpathe.com/video/queen-marys-

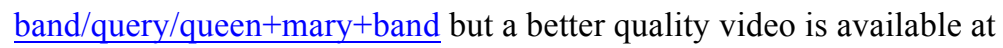
https://www.youtube.com/watch?v=J1ZL-OqfhQ8

${ }^{15}$ It is perhaps telling of this narrative of musical transatlanticism that the band perform a British song, “The Fleet's in Port Again" by Noel Gay, in a jazzy vein and an American song, "It Looks Like Rain in Cherry Blossom Lane" by Edgar Leslie and Joe Burke, in a pseudo-classical style.

${ }^{16}$ Waller in Vance, Fats Waller, 122.

17 "Piccadilly" was entitled "Piccadilly Party" on a 1950 release by RCA Victor that was offered as a Christmas gift to record reviewers. Bob Kumm's 1967 Storyville article on Ed Kirkeby suggests the piece, recorded under that name, was intended as a warm-up for Waller's recording session and not as the opening part of the suite that it subsequently became. See Kumm, "Ed Kirkeby”, 6.

${ }^{18}$ The business correspondence files in the Kirkeby Collection at Rutgers includes several descriptions of the movements of the suite that relate the character of the appropriate districts of London to the music.

${ }^{19}$ Charles Fox reported that Lewin "failed to produce any kind of beat" and was thus relegated to a minimal role in the recording session by Waller. See Fox, Fats Waller, 67. Stephen Taylor's discography indicates Lewin as "possibly" in "Piccadilly" as well as "Bond Street" but I cannot hear any evidence to support this possibility. See Taylor, On the Air, 251. 
${ }^{20}$ Many of same devices are featured in Waller's re-conception of Jimmy McHugh and Dorothy Field's song “A Japanese Dream”. Waller never recorded the number but the published score is in Schiff, Jazz, Blues, Boogie, 90-91.

${ }^{21}$ The use of $\mathrm{C}$ minor provides the suite with a formal symmetry and a unity, as it is the key of the opening movement, "Piccadilly".

${ }^{22}$ Business Correspondence comprises Subseries 3B of the collection. The letters concerning the London Suite are split between boxes 5 and 6 of the collection. Box 5 covers the period June 1939February 1945 in folders 42-45 and Box 6 covers March 1945-April 1962 in folders 1-7.

${ }^{23}$ According to Laurie Wright, the composition and private recording of the London Suite took place in Billy Higgs recording studio in London on Sunday 2 April 1939. See Wright, “Fats” in Fact, 208-209. The acetate recordings survived and although unissued by any record company are known to record collectors through a few dubbed copies of the set owned by Ed Kirkeby.

${ }^{24}$ See Kirkeby to Ben Kempter, 1. Stephen Taylor agrees with Lawrie Wright that the HMV session took place on 13 June 1939. See Taylor, On the Air, 251. However, as Wright points out, there is confusion over the timing of the Higgs session which he dates to 2 April (See Wright, Fats in Fact, 208). Kirkeby maintained the HMV session was conducted the day after the Higgs one, which occurred on a Sunday but an article in Melody Maker indicates the Higgs session must have occurred before 8 April 1939.

${ }^{25}$ Several letters exchanged between Kirkeby and Phillips in the period 1942-1945 discuss the reticence of Shapiro Bernstein to produce a score. The decision that Peter Maurice should prepare a publication of Waller's suite was taken in the summer of 1945, as is detailed in a letter from Phillips to Ed Kirkeby of 18 June 1945, 1.

${ }^{26}$ Letters of 17 November 1941 and 17 September 1942 between Stephen Sholes of the RCA Manufacturing Company and Ed Kirkeby make the situation clear.

${ }^{27}$ Philips wrote to Ed Kirkeby on 27 March 1945 to suggest Gray as arranger. In the end, as Phillips reported in a letter of 22 August 1945, Gray produced an arrangement of just the "Chelsea" movement. Kirkeby also wrote to Paul Whiteman on 18 July 1945 to get him interested and consorted with Phillips to get Agnes de Mille to consider a ballet based on Waller's suite but nothing seems to have come of these approaches. See Kirkeby to Anna G. DeMille, 1 and Kirkeby to Jimmy Phillips, 18 July 1945, 1 and Phillips to Ed Kirkeby, 22 August 1945, 1. 
${ }^{28}$ No doubt aware of impending financial pressures resulting from the loss of his prime asset, Kirkeby wrote to Phillips on 19 December 1947 to claim co-author rights over a number of Waller's works including the London Suite. Phillips replied on 31 December 1947 that it was too late to co-credit Kirkeby as an author on the sheet music but if a second printing were required he would add the wording “As Suggested by Ed Kirkeby”. Phillips to Ed Kirkeby, 31 December 1947, 1.

${ }^{29}$ Although some commentators have claimed the masters were destroyed in the London bombings, it seems more likely that HMV deliberately destroyed the masters, perhaps in order to reuse the shellac for other recordings, as it was in short supply during the war.

${ }^{30}$ It seems that the damage was to the "Bond Street" disk (the dubbings were on single-sided records) and this was responsible for the delay in releasing the suite in Waller's recordings. A letter of 23 November 1950, between Kirkeby and Ben Kemper of RCA suggests it was only when Kirkeby located a copy of "Bond Street” in Peter Maurice's London offices earlier in 1950 that HMV consented to release Waller's recording.

${ }^{31}$ Heath, "Fats" Waller's London Suite, liner notes.

${ }^{32}$ Heath, Listen (1957), 78.

${ }^{33}$ Gronow and Saunio, An International History, 90-91.

${ }^{34}$ The album catalogue number, LA6, suggests it was only the sixth album to be produced on the London label.

${ }^{35}$ The 1948 album liner notes list Eric Jupp as the arranger of "Soho", "Limehouse" and "Piccadilly", Bruce Campbell as arranger of "Bond Street”, Reg Briggs as arranger of "Whitechapel” and Alan Bristow as arranger of "Chelsea".

${ }^{36}$ Hollywood Lead Sheet, "Disk Reviews", 13.

${ }^{37}$ Kolodin, "Impressions", 47.

${ }^{38}$ Watt, "Popular Records", 102. Watt published these early reviews under his initials D. W.

${ }^{39}$ Taubman, "Records", X4.

${ }^{40}$ Jackson, “"Fats' Waller Piano Solos”, 36.

41 The use of Owen for all six movements of the suite may well have been to achieve a greater consistency in musical style than in the 1948 version which used four arrangers.

${ }^{42}$ Sampson, "New Fats Waller Version”, T24.

${ }^{43}$ DeVeaux, "Constructing the Jazz Tradition”, 525-560. 
${ }^{44}$ Gilroy, Black Atlantic, 72-110.

${ }^{45}$ One notable exception here is the consideration by George McKay in his book, Circular Breathing, which seeks to develop the notion of jazz as a more global culture with reference to Gilroy's concept of the Black Atlantic with particular reference to exchanges between Britain and the Commonwealth. See McKay, Circular Breathing, 129-191.

46 Gilroy, Black Atlantic, 30

${ }^{47}$ Gilroy, Black Atlantic, xi.

48 Ibid. 


\section{References}

British Pathé. “Queen Mary’s Band. (1938)”. Newsreel on YouTube. Accessed July 23, 2016. https://www.youtube.com/watch?v=JlZL-OqfhQ8

Darnell, H. C. to Ed Kirkeby. Camden, New Jersey, 3 April 1944. The Wallace Theodore "Ed" Kirkeby Collection, Institute of Jazz Studies, Rutgers University Libraries, Box 5, Folder 45.

DeVeaux, Scott. "Constructing the Jazz Tradition: Jazz Historiography”. In Black America Literature Forum 25, no. 3 (1991): 525-560.

Fox, Charles. Fats Waller. Vol. 7, Kings of Jazz. London: Cassell, 1992.

Gilroy, Paul. The Black Atlantic: Modernity and Double Consciousness. London: Verso, 1993.

Gofffin, Robert. Jazz: from Congo to Swing, translated by Ray Sonin. London: Musicians Press, 1946.

Gottleib, Robert. Reading Jazz: A Gathering of Autobiography, Reportage, and Criticsm. St. Ives: Clays, 1999.

Gronow, Pekka and Lipo Saunio. An International History of the Recording Industry. Translated by Christopher Moseley. London and New York: Cassell, 1999.

Heath, Ted, dir. "Fats” Waller's “London Suite”. Album liner notes. New York: London Gramophone Corp., LA-6, 1948.

Heath, Ted. Listen to My Music. London: Muller, 1957.

Heath, Ted. Listen to My Music Vol. 3 '47-48. CD liner notes. HEPCD 61, 1993. Hollywood Lead Sheet. “Disk Reviews”. Hollywood Lead Sheet. June 1948, 13. Jackson, Edgar. “'Fats’ Waller - Piano Solos”. Gramophone, May, 1951, 36.

Kirkeby, Ed. Ain't Misbehavin': The Story of Fats Waller. London: Jazz Book Club, 1967. 
Kirkeby, Ed. to Anna G. DeMille. New York, 18 July 1945. The Wallace Theodore “Ed” Kirkeby Collection, Institute of Jazz Studies, Rutgers University Libraries, Box 6, Folder 1.

Kirkeby, Ed to Ben Kempter. London, 23 November 1950. The Wallace Theodore “Ed” Kirkeby Collection, Institute of Jazz Studies, Rutgers University Libraries, Box 6, Folder 4.

Kirkeby, Ed to Jimmy Phillips. New York, 2 May 1944. The Wallace Theodore "Ed" Kirkeby Collection, Institute of Jazz Studies, Rutgers University Libraries, Box 5, Folder 45.

Kirkeby, Ed to Jimmy Phillips. New York, 19 December 1947. The Wallace

Theodore "Ed” Kirkeby Collection, Institute of Jazz Studies, Rutgers University Libraries, Box 6, Folder 2.

Kirkeby, Ed to Paul Whiteman. New York, 21 August 1945. The Wallace Theodore “Ed” Kirkeby Collection, Institute of Jazz Studies, Rutgers University Libraries, Box 6, Folder 1.

Kirkeby, Ed to Jimmy Phillips. New York, 18 July 1945. The Wallace Theodore "Ed" Kirkeby Collection, Institute of Jazz Studies, Rutgers University Libraries, Box 6 , Folder 1.

Kolodin, Irving. “Impressions”. Saturday Review of Literature. April 24, 1948, 47. Kumm, Bob. "Ed Kirkeby: 50 Years in the Record Business". Storyville. OctoberNovember, 1967, 3-7.

Machlin, Paul. Stride: The Music of Fats Waller. London: MacMillan, 1985.

MacKay, George. Circular Breathing: The Cultural Politics of Jazz in Britain.

Durham and London: Duke University Press, 2005. 
Panassié, Hugues. Hot Jazz: The Guide to Swing Music, translated by Lyle and Eleanor Dowling, revised by the author for the English language edition. New York: Witmark, 1936.

Phillips, Jimmy to Ed Kirkeby. London, 18 June 1945. The Wallace Theodore "Ed" Kirkeby Collection, Istitute of Jazz Studies, Rutgers University Libraries, Box 6, Folder 1.

Phillips, Jimmy to Ed Kirkeby. London, 31 December 1947. The Wallace Theodore “Ed” Kirkeby Collection, Istitute of Jazz Studies, Rutgers University Libraries, Box 6, Folder 1.

Phillips, Jimmy to Ed Kirkeby. London, 27 March 1945. The Wallace Theodore "Ed" Kirkeby Collection, Institute of Jazz Studies, Rutgers University Libraries, Box 6 , Folder 1.

Phillips, Jimmy to Ed Kirkeby. London, 22 August 1945. The Wallace Theodore “Ed” Kirkeby Collection, Institute of Jazz Studies, Rutgers University Libraries, Box 6, Folder 1.

Phillips, Jimmy to Ed Kirkeby. London, 31 May 1944. The Wallace Theodore "Ed" Kirkeby Collection, Institute of Jazz Studies, Rutgers University Libraries, Box 5 , Folder 45.

Sampson, Paul. "New Fats Waller Version". The Washington Post and Times Herald. May 23, 1954, 24.

Schiff, Ronny S., ed. Jazz, Blues, Boogie \& Swing for Piano. Milwaukee, Wisconsin: Hal Leonard, 2000.

Shipton, Alyn. Fats Waller: His Life and Times. Tumbridge Wells: Spellmont, 1988. Shipton, Alyn. Fats Waller: The Cheerful Little Earful. London: Continuum, 2001. 
Sholes, Stephen to Ed Kirkeby. Camden, New Jersey, 17 November 1941. The Wallace Theodore "Ed” Kirkeby Collection, Istitute of Jazz Studies, Rutgers University Libraries, Box 5, Folder 44.

Sholes, Stephen to Ed Kirkeby. Camden, New Jersey, 17 September 1942. The Wallace Theodore "Ed" Kirkeby Collection, Istitute of Jazz Studies, Rutgers University Libraries, Box 5, Folder 44.

Taubman, Howard. "Records: Koussevitzky Leads Beethoven's Ninth”. The New York Times, April 11, 1948, 4.

Taylor, Helen. Cirling Dixie: Contemporary Southern Culture through a Transatlantic Lens. New Brunswick: Rutgers University Press, 2001.

Taylor, Stephen. Fats Waller On the Air: The Radio Broadcasts and Discography. Lanham, MD: Scarecrow, 2012.

Vance, Joel. Fats Waller: His Life and Times. London: Robson Books, 1979.

Waller, Fats. "Fats" Waller's Famous London Suite. Transcribed piano score. London: Peter Maurice, 1947.

“Waller, Fats - Ain't Misbehavin'.” Encyclopedia of Popular Music, 4th ed. Oxford Music Online. Oxford University Press, accessed July 18, 2016, http://www.oxfordmusiconline.com/subscriber/article/epm/89898.

Waller, Maurice and Anthony Calabrese. Fats Waller. New York: Schirmer Books, 1977.

Watt, Douglas. "Popular Records". The New Yorker. April 17, 1948, 101-102.

Wright, Laurie. "Fats" in Fact. Chigwell: Storyville, 1992. 